\title{
Chemokines Regulate the Migration of Neural Progenitors to Sites of Neuroinflammation
}

\author{
Abdelhak Belmadani, ${ }^{\star}$ Phuong B. Tran, ${ }^{\star}$ Dongjun Ren, and Richard J. Miller \\ Department of Molecular Pharmacology and Biological Chemistry, Northwestern University Medical School, Chicago, Illinois 60611
}

\begin{abstract}
Many studies have shown that transplanted or endogenous neural progenitor cells will migrate toward damaged areas of the brain. However, the mechanism underlying this effect is not clear. Here we report that, using hippocampal slice cultures, grafted neural progenitor cells (NPs) migrate toward areas of neuroinflammation and that chemokines are a major regulator of this process. Migration of NPs was observed after injecting an inflammatory stimulus into the area of the fimbria and transplanting enhanced green fluorescent protein (EGFP)-labeled NPs into the dentate gyrus of cultured hippocampal slices. Three to $7 \mathrm{~d}$ after transplantation, EGFP-NPs in control slices showed little tendency to migrate and had differentiated into neurons and glia. In contrast, in slices injected with inflammatory stimuli, EGFP-NPs migrated toward the site of the injection. NPs in these slices also survived less well. The inflammatory stimuli used were a combination of the cytokines tumor necrosis factor- $\alpha$ and interferon- $\gamma$, the bacterial toxin lipopolysaccharide, the human immunodeficiency virus- 1 coat protein glycoprotein 120 , or a $\beta$-amyloid-expressing adenovirus. We showed that these inflammatory stimuli increased the synthesis of numerous chemokines and cytokines by hippocampal slices. When EGFP-NPs from CC chemokine receptor $\mathrm{CCR}_{2}$ knock-out mice were transplanted into slices, they exhibited little migration toward sites of inflammation. Similarly, wild-type EGFP-NPs exhibited little migration toward inflammatory sites when transplanted into slices prepared from monocyte chemoattractant protein-1 (MCP-1) knock-out mice. These data indicate that factors secreted by sites of neuroinflammation are attractive to neural progenitors and suggest that chemokines such as MCP-1 play an important role in this process.
\end{abstract}

Key words: $\mathrm{CCR}_{2}$ receptors; $\mathrm{MCP}-1$; migration; neural progenitors; neurogenesis; neuroinflammation; neural precursor

\section{Introduction}

The use of neural progenitors (NPs) for repairing brain damage is a subject of great interest (Gage, 2002; Parent, 2003; Lindvall et al., 2004), holding out the hope of actually reversing, rather than merely attenuating, neurodegeneration associated with many brain disorders (Fricker et al., 1999; Aboody et al., 2000; PicardRiera et al., 2002; Iwai et al., 2003; Imitola et al., 2004; Jin et al., 2004; Kelly et al., 2004; Pluchino et al., 2005). To achieve this aim, neural progenitors must migrate to regions of brain injury, differentiate into cells with the correct phenotype, and integrate appropriately into a neuronal circuits (Abrous et al., 2005). The potential of neural progenitors for performing these tasks has been demonstrated in cell culture and in vivo using animal models of brain disease (Gage, 2002; Abrous et al., 2005). However, our understanding as to how all of these processes occur and how they can be manipulated to therapeutic advantage is incomplete. It has frequently been demonstrated that neural progenitors

Received July 29, 2005; revised Feb. 5, 2006; accepted Feb. 7, 2006.

This work was supported by National Institutes of Health Grants R01NS043095, R01DA013141, and R37MH040165. We thank Dr. William J. Karpus for providing us with $\mathrm{CCR}_{2}$ and MCP-1 K0 mice, Dr. Jaime Grutzendler

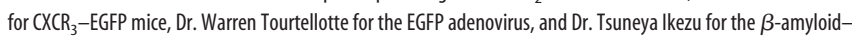
GFP adenovirus. A special thank you goes to Dr. Peter Toth for his technical assistance with MetaMorph software

${ }^{*}$ A.B. and P.B.T. contributed equally to this work.

Correspondence should be addressed to Prof. Richard J. Miller, Department of Molecular Pharmacology and Biological Chemistry, Northwestern University, 303 East Chicago Avenue, Ward 8-296, Chicago, IL 60611. E-mail: r-miller10@northwestern.edu.

DOI:10.1523/JNEUROSCI.0156-06.2006

Copyright (C) 2006 Society for Neuroscience $\quad 0270-6474 / 06 / 263182-10 \$ 15.00 / 0$ transplanted into the brain will migrate toward either localized (e.g., stroke) or diffuse (e.g., demyelinated) areas of brain damage (Fricker et al., 1999; Aboody et al., 2000; Arvidsson et al., 2002; Ehtesham et al., 2002; Iwai et al., 2003; Yip et al., 2003; Glass et al., 2005). These observations suggest that factors associated with damaged areas of the brain can direct the migration of progenitors. Infection of the brain, trauma, neurodegeneration, or other types of brain injury usually result in a neuroinflammatory response involving components of the innate immune system of the brain, including the activation of astrocytes and microglia (Huang et al., 2000; Aarum et al., 2003; DeLeo et al., 2004). One consequence of this response is the upregulation of cytokine and chemokine synthesis by these activated cells (Huang et al., 2001; Babcock et al., 2003). Chemokines are small secreted proteins that have been shown to play a key role in the organization of leukocyte migration under normal conditions as well as during neuroinflammatory responses (Huang et al., 2000, 2001; Tran and Miller, 2003). Recently, chemokines have been shown to play a role in directing the migration of neural progenitors in the developing brain (Zou et al., 1998; Lu et al., 2002; Stumm et al., 2003; Tran and Miller, 2003) and peripheral nervous system (Belmadani et al., 2005). We demonstrated that neural progenitors prepared from the postnatal brain express numerous chemokine receptors, and that neural progenitors in neurogenic regions of the brain normally express these receptors (Tran et al., 2004a). We therefore hypothesized that chemokines released from sites of neuroinflammation might help to guide the migration of neural progenitors to damaged areas of the brain. 


\section{Materials and Methods}

Animals. CD1 (ICR; Charles River Laboratories, Wilmington, MA), B6 $\times$ 129, C57BL/6J (The Jackson Laboratory, Bar Harbor, ME), C57BL/6J mutant mice and $\mathrm{BALB} / \mathrm{c} \mathrm{CX} 3 \mathrm{CR}_{1}$ - enhanced green fluorescent protein (EGFP) were used in these experiments, and all animal experimentation protocols were approved by the Northwestern University Animal Care and Use Committee. Mice lacking the $\mathrm{CC}$ chemokine receptor $\mathrm{CCR}_{2}$, i.e., $\mathrm{CCR}_{2}{ }^{-1-}$ from the $\mathrm{B} 6 \times 129$ strain and monocyte chemoattractant protein-1 (MCP-1) [i.e., MCP-1 ${ }^{-1-}$ from the $(129 \mathrm{~Sv} / \mathrm{J} \times \mathrm{C} 57 \mathrm{BL} / 6) \mathrm{F}_{1}$ strain], were generous gifts from Dr. William J. Karpus (Northwestern University, Chicago, IL) and have been characterized previously (Kuziel et al., 1997; Lu et al., 1998). Heterozygous $\mathrm{CX}_{3} \mathrm{CR}_{1}{ }^{\mathrm{GFP} /+}$ mice were a generous gift from Dr. Jaime Grutzendler (Northwestern University), and their phenotype has been described previously (Jung et al., 2000).

Preparation of organotypic hippocampal slice culture. Seven-day-old CD1 mice were killed by decapitation, and the brains and meninges were removed under aseptic conditions, followed by separation of the hippocampus from the two hemispheres. As described by Belmadani et al. (2001), the hippocampal tissue blocks were cut by a McIlwain tissue chopper into $350-\mu \mathrm{m}$-thick coronal slices. The slices (three to four) were placed on semiporous membrane inserts (Millicell-CM, $0.4 \mu \mathrm{m}$; Millipore, Bedford, MA) and transferred to six-well culture plate with $1.2 \mathrm{ml}$ of MEM supplemented with 25\% horse serum (Invitrogen, Carlsbad, CA), $6.5 \mathrm{mg} / \mathrm{ml} \mathrm{D-glucose} \mathrm{(Sigma,} \mathrm{St.} \mathrm{Louis,} \mathrm{MO),} \mathrm{and} 0.5 \mathrm{~mm}$ L-glutamine. After $3 \mathrm{~d}$ in cultures, the medium was changed to serumfree Neurobasal medium (Invitrogen) with 2\% B27 supplement (Invitrogen), $6.5 \mathrm{mg} / \mathrm{ml} \mathrm{D}$-glucose, and $0.5 \mathrm{~mm}$ L-glutamine with subsequent medium change twice a week. In other experiments, slices were prepared from MCP-1 mutant mice, $\mathrm{CXCR}_{3}-\mathrm{EGFP}$, mice or $\mathrm{B} 6 \times 129 \mathrm{PF} 2 / \mathrm{J}$ mice as controls for $\mathrm{CCR}_{2}$ mutant mice.

Propagation of mouse neurospheres and micrografting. Subventricular zone (SVZ) blocks were dissected from 5- to 7-d-old CD1 mice, dissociated via repeated trituration, and grown in flasks in medium containing Neurobasal/B27/N2 media supplemented with heparin $(2 \mu \mathrm{g} / \mathrm{ml}$; Sigma), epidermal growth factor (10 ng/ml; Sigma), or basic fibroblast growth factor (10 ng/ml; BD Biosciences, Franklin Lakes, NJ), as described by Tran et al. (2004a). After $7 \mathrm{~d}$ in cultures, the resulting neurospheres were dissociated into single cells that were cultured for an additional $7 \mathrm{~d}$ to form secondary neurospheres. They were then transfected with a green fluorescent protein vector (gift from Dr. Warren Tourtellotte, Northwestern University), and EGFP expression of neurospheres was routinely checked using fluorescent microscope. After 3-4 d in cultures, green neurospheres were enzymatically dissociated $(25 \mathrm{mg} / \mathrm{ml}$ trypsin/EDTA), counted, and loaded on the tip of a $0.5 \mu$ l Hamilton syringe mounted on a micromanipulator. Suspensions of these cells (34000 cells/ $0.2 \mu \mathrm{l}$ ) were seeded locally onto the culture in the area of the dentate gyrus (DG) as indicated in Figure 1. After 3-7 d in culture, grafted slices were analyzed by confocal microscopy for cell migration or processed for immunostaining. In some experiments, dissociated neurospheres were labeled with PKH26 dye (red fluorescent linker; Sigma) before transplantation. In other experiments, neurospheres were generated from the SVZ of $\mathrm{CCR}_{2}$ mutant mice.

Neuroinflammation. A neuroinflammatory response was achieved by injecting $0.1-0.2 \mu \mathrm{l}$ of solution of an inflammatory stimulus (or control solution) into the area of the fimbria of cultured hippocampal slices using a $0.5 \mu \mathrm{l}$ Hamilton syringe mounted on a micromanipulator. The inflammatory stimuli used were a combination of the cytokines tumor necrosis factor- $\alpha$ (TNF- $\alpha$ ) and interferon- $\gamma$ (IFN- $\gamma$ ) (20 ng each), the bacterial toxin lipopolysaccharide (LPS) $(10 \mu \mathrm{M})$, the human immunodeficiency virus-1 (HIV-1) coat protein glycoprotein 120 (gp120) (250 pM), or a recombinant adenovirus coexpressing EGFP and $\beta$-amyloid (3 nм) (Ikezu et al., 2003). In the controls, we used injection of saline solution of comparable volume $(0.1-0.2 \mu \mathrm{l})$. Of note, injections of $0.1-$ $0.2 \mu \mathrm{l}$ were performed using a $0.5 \mu \mathrm{l}$ Hamilton syringe operated by a manual micrometric stage mounted on a microscope under a $10 \times$ objective.

Quantification of cell migration. After transplantation of labeled cells, the cultures were incubated for $24 \mathrm{~h}$ to settle, imaged, further incubated for 3, 7, and $15 \mathrm{~d}$, and then fixed in paraformaldehyde (4\%). They were rinsed in PBS, mounted, and examined using confocal microscopy. Confocal images were further processed for cell migration using MetaMorph software (Universal Imaging Corporation, Downington, Chester, PA). The average distance between the site of injection and 25-50 green (or red) cells was calculated in each slice and expressed as a migratory distance (MD) in micrometers.

Immunohistochemistry. Fixed cultures (slices and grafted cells) were washed in PBS, permeabilized with $0.1 \%$ Triton X-100 (Sigma), and incubated with primary antibodies diluted in blocking solution overnight at $4^{\circ} \mathrm{C}$. The following primary antibodies were used: glial fibrillary acidic protein (GFAP) (mouse IgG, 1:300; Sigma), nestin (mouse IgG, 1:300; PharMingen, San Diego, CA), and neuronal-specific nuclear protein (NeuN) (mouse IgG1, 1:300). A combination of CD11b (mouse IgG1, 1:400; PharMingen) and F4/80 (rat IgG2b, 1:50; Caltag, South San Francisco, CA) antibodies was also used to stain for macrophages and microglia. After washing in blocking solution, the appropriate isotypespecific secondary antibodies labeled with Alexa Fluor 488-, Alexa Fluor 633-, and Alexa Fluor 543-conjugated preparations (1:500; Invitrogen) were applied, and the cultures were incubated for $1 \mathrm{~h}$. After repeated washing in PBS, cultures were mounted using Vectashield containing $4^{\prime}, 6^{\prime}$-diamidino-2-phenylindole (DAPI) (Vector Laboratories, Burlingame, CA) and analyzed using a confocal microscope.

To examine colocalized expression patterns, two-color confocal imaging was performed with an Olympus Optical (Melville, NY) Fluoview laser scanning confocal microscope system (FV500; Olympus Optical). EGFP-transfected cells were excited at $488 \mathrm{~nm}$ using an argon laser, and Alexa Fluor-543- and Alexa Fluor-633-tagged secondary antibodies were visualized by excitation at 543 and $633 \mathrm{~nm}$ with a helium-neon laser. Images were acquired sequentially in the appropriate channels. Optical sections $(0.175 \mu \mathrm{m})$ were collected as stacked $z$-dimension images. The $z$-dimension reconstructions were inspected orthogonally in both the horizontal and vertical planes. Orthogonal planes were obtained off-line using the MetaMorph image analysis software. Cells were considered as double labeled if three independent researchers judged colocalization from all observation angles using the off-line version of MetaMorph. Dendritic structures growing deep into the tissue were visualized in extended focus $z$-projection images. To determine the number of transplanted cells becoming glia or neurons, cultured slices were fixed and processed for immunohistochemistry. Confocal images of EGFP expression and DAPI staining were obtained using a Zeiss (Oberkochen, Germany) 510 Meta confocal microscope with a UV laser and merged to show DAPI-EGFP-expressing cells. An average of 20-25 DAPI-GFPlabeled cells per slice were analyzed for neuronal and glial differentiation, and the proportion of GFAP- or NeuN-positive cells was determined as a percentage \pm SEM of DAPI-positive cells.

Quantification of cell survival of grafted cells. Fixed cultures were processed directly for measurement of the intensity of EGFP fluorescence using MetaMorph software. Some cultures were used for the detection and the quantification of cell death using In Situ Cell Detection kit, fluorescein, or tetramethylrhodamine red [terminal deoxynucleotidyl transferase-mediated biotinylated UTP nick end labeling (TUNEL) assay] following the instructions of the manufacturer (Roche, Indianapolis, IN).

Quantification of chemokine concentrations. Culture medium $(25 \mu \mathrm{l})$ from control and treated slices were used to measure chemokine and cytokine levels by a LINCOplex immunoassay (LINCO Research, St. Charles, MI). Briefly, The assay is based on the Luminex 100 IS technology and uses color-coded microparticles to which are coupled antibodies specific to the cytokines/chemokines of interest. Microparticles, standards, and samples are pipetted into wells of a 98-well plate, and the specific antibodies captures the analytes (cytokines/chemokines) of interest. Biotinylated antibodies specific to the analytes are added and form an antibody-antigen sandwich. Streptavidin-phycoerythrin (PE) are added to generate a signal. The microparticles are read using a Luminex 100 IS dual-laser analyzer: one laser classifies the microparticle and determines the analyte that is being detected, and the second laser determines the magnitude of the PE-derived signal that is in direct proportion to the amount of analyte bound. 
Statistical analysis. Results were analyzed with ANOVA with Bonferroni's post hoc tests. $p$ values $<0.05$ were considered significant. The number of different experiment $(n)$ and the number of slices used per group and per experiment are indicated for each experiment. The number of cells counted per slice is indicated above.

\section{Results}

Differentiation of postnatal neural progenitors in cultured mouse

hippocampal slices

The paradigm that we used in these studies was to examine the migration and development of NPs transplanted into the area of the DG of mouse hippocampal slice cultures (MHSCs) (CD1 strain) (supplemental Fig. S1 A, available at www.jneurosci. org as supplemental material). We used NPs isolated from the SVZ of wild-type (WT) mice (5- to 7-d-old) and grown as neurospheres. Neurospheres can be labeled with EGFP using an adenoviral vector (supplemental Fig. S1C, available at www.jneurosci.org as supplemental material). Alternatively, cells can be labeled with $\mathrm{PKH} 26$, a red fluorescent lipophilic dye that binds irreversibly to cell membranes (supplemental Fig. S1C', available at www. jneurosci.org as supplemental material). The neurospheres can be enzymatically dissociated into single cells and used as EGFP-NPs or PKH26-NPs for transplantation purposes.

Mouse hippocampal slice cultures were prepared as described by Belmadani et al. (2001). These slices can be grown for several weeks while retaining their basic cellular organization and intrinsic connections (supplemental Fig. S1 A, available at www. jneurosci.org as supplemental material). We microinjected suspensions of labeled WT NPs (3-4000 cells/ $0.2 \mu \mathrm{l})$ into the area of the DG of MHSCs (supplemental Fig. S1, available at www.jneurosci.org as supplemental material). Although many cells were washed away during this procedure, numerous green fluorescent cells were found to be stably integrated into the slices when examined several hours or days later. Initially, these cells maintained the spherical morphology of dissociated progenitor cells (Fig. 1A,B) and expressed the progenitor cell marker nestin (Fig. 2). However, after 3-7 d, there was a dramatic change in their morphology. Most cells developed a highly differentiated morphology resembling neurons or glia (Fig. $1 C$ ). We further examined the phenotype of these cells by staining slices with markers specific for neurons (Fig. 3, NeuN) or glia (Fig. 4, GFAP).

\section{Migration and differentiation of neural progenitor cells in response to inflammation}

To test the migratory ability of NPs in response to neuroinflammation, we attempted to produce a neuroinflammatory response within 7-d-old MHSCs. To do this, we injected an inflammatory
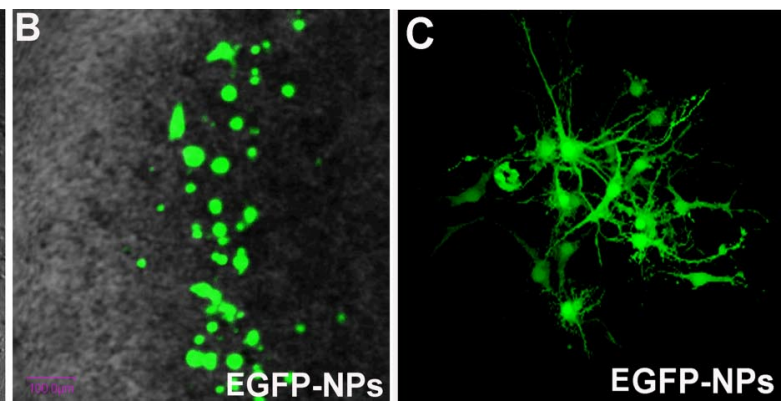

Figure 1. Developmental potential of NPs expressing EGFP (green cells). $\boldsymbol{A}$, Confocal image of EGFP-NPs transplanted into the area of the dentate gyrus $(\mathrm{dg})$ of a cultured mouse hippocampal slice after $18 \mathrm{~h}$ in culture, illustrating the spherical morphology of cells, similar to that of dissociated neurospheres (as illustrated in $\boldsymbol{C}$ ). Scale bar, $500 \mu \mathrm{m}$. $\boldsymbol{A}$ is magnified in $\boldsymbol{B}$. Scale bar, $100 \mu \mathrm{m}$. $\boldsymbol{C}$ Confocal image showing grafted EGFP-NPs have differentiated into cells with neuronal and glial morphology after 3-5 $\mathrm{d}$ in
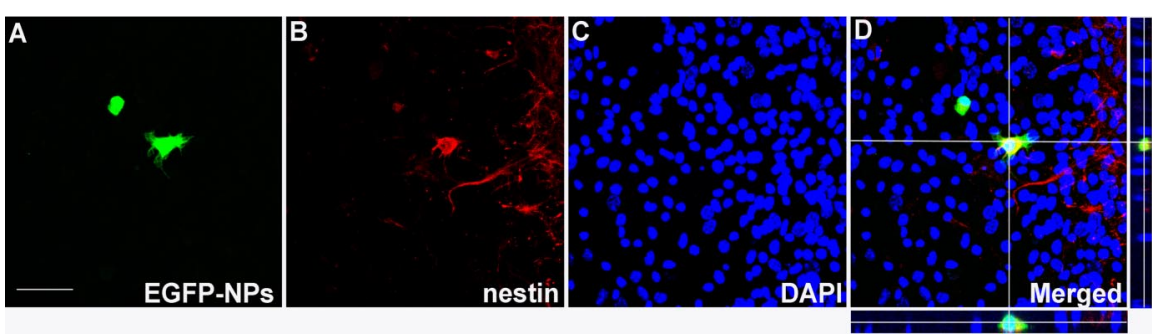

Figure 2. Undifferentiated phenotype typical of EGFP-NPs $48 \mathrm{~h}$ after transplantation into the dentate gyrus of 7-d-old hippocampal slice cultures. $\boldsymbol{A}, \boldsymbol{B}$, Double-fluorescent confocal images of neural progenitor cells: EGFP ( $\boldsymbol{A}$, green) and anti-nestin ( $\boldsymbol{B}$ red). $\boldsymbol{C}$, DNA was visualized by staining with DAPI. $\boldsymbol{D}$, Three-dimensional analysis of a double-fluorescent confocal image of an NP EGFP (green) and anti-nestin (red). The $\boldsymbol{x}-\boldsymbol{z}$ and $\boldsymbol{y} \mathbf{- z}$ images are shown. $n=6$ and 9 slices per experiment were used. Scale bar,
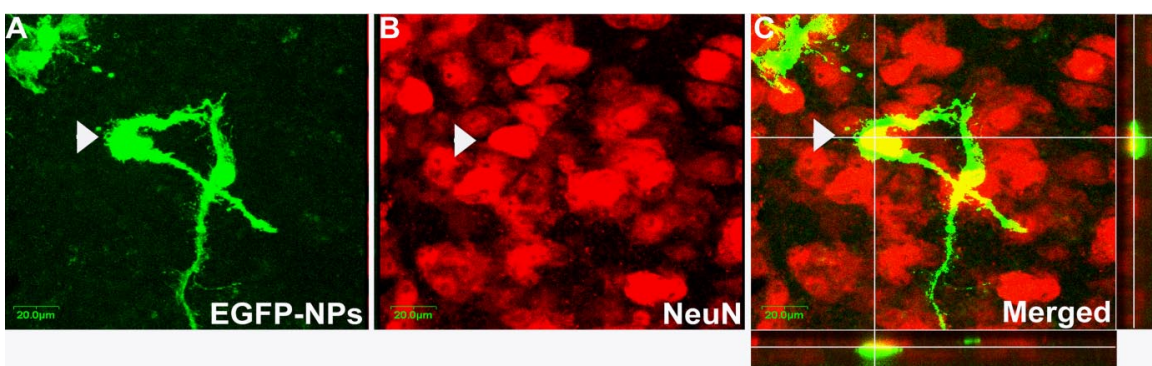

Figure 3. Confocal images showing neuronal differentiation of grafted NPs after transplantation of EGFP-NPs into the dentate gyrus of 7-d-old hippocampal slice cultures. After 3-7 d, some grafted EGFP-NPs (green, arrowhead in $\boldsymbol{A}$ ) stained for NeuN (red, in $\boldsymbol{B}$ and in merged image, yellow, in $\boldsymbol{C}$. $\boldsymbol{C}$, Three-dimensional analysis of double-fluorescent confocal image of NPs: EGFP (green) and anti-NeuN (red). In control slices, 9 of 230 EGFP-labeled cells were NeuN positive and 3 of 98 EGFP cells were NeuN positive in TNF- $\alpha$-IFN- $\gamma$-injected slices. $n=3,6$ slices per group per experiment. Scale bars, $20 \mu \mathrm{m}$.

stimulus, such as a combination of TNF- $\alpha-$ IFN- $\gamma$, into the area of the fimbria of the slice. Sixteen hours later, 3-4000 EGFPexpressing progenitor cells were injected into the DG of the slice (schematic green spots in supplemental Fig. S1 $B$, available at www.jneurosci.org as supplemental material). In preliminary experiments, we tested the accuracy of the injections by using an EGFP-expressing adenoviral vector that indicated the local nature of the injections (Fig. 5A).

We examined the position and phenotypes of cells 3-5 d after progenitor cell injection. In control slices (no cytokines, saline injection), grafted cells remained in the vicinity of the DG injection site (Fig. $5 B$ ). In contrast, in MHSC cultures that had been injected with TNF- $\alpha$-IFN- $\gamma$ for $16 \mathrm{~h}$, many EGFP-labeled progenitors had migrated away from the DG into the parenchyma of the slice toward the site of cytokine injection (Fig. 5C). In both 

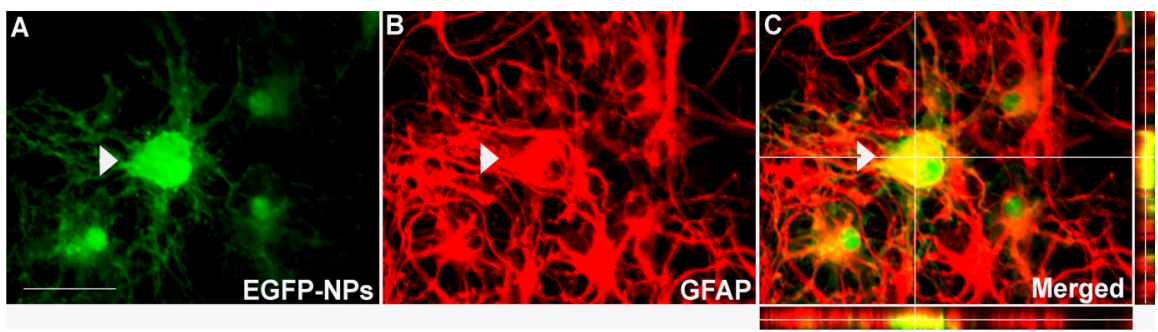

Figure 4. Confocal images showing astrocyte differentiation of grafted NPs after transplantation of EGFP-NPs into the dentate gyrus of 7-d-old hippocampal slice cultures. After 3-7 d, some grafted EGFP-NPs (green, arrowhead in $\boldsymbol{A}$ ) stained for GFAP (red, arrowhead in $\boldsymbol{B}$ and in merged image, yellow, in C. C, Three-dimensional analysis of a double-fluorescent confocal image of NPs: EGFP (green) and anti-GFAP (red). The $\boldsymbol{x}-\boldsymbol{z}$ and $\boldsymbol{y}-\boldsymbol{z}$ images are shown. One hundred fifty-five of 253 EGFP cells were GFAP positive (61 $\pm 5 \%$ ) in control slices, and 106 of 138 EGFP cells were GFAP positive (77 $\pm 7 \%$ ) in TNF- $\alpha$-IFN- $\gamma$-injected slices. $n=3,6$ slices/ per group per experiment. Scale bar, $50 \mu \mathrm{m}$
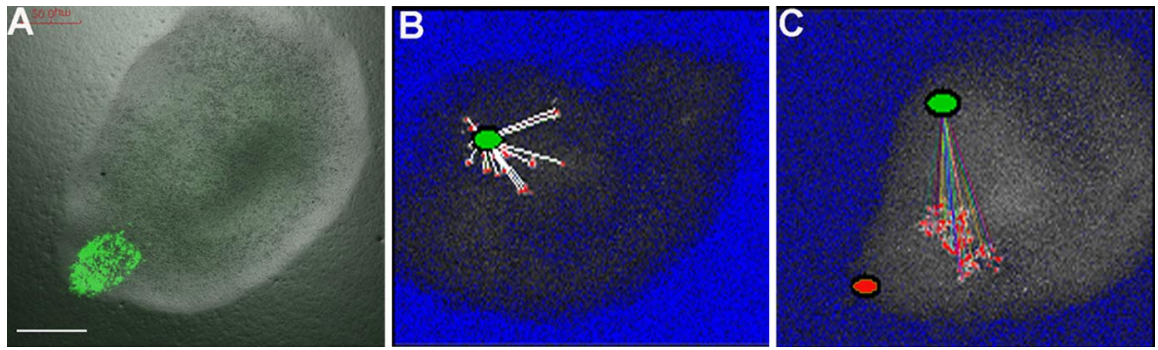

Figure 5. Patterns of migration of EGFP-NPs 3-5 d after injection of an inflammatory stimulus into the area of the fimbria (red dot in C, followed by transplantation of EGFP-NPs (green dot in $\boldsymbol{B}$ and $\boldsymbol{C}$ ) into the dentate gyrus of 7-d-old hippocampal slice cultures. Confocal images were further processed for assessment of cell migration using MetaMorph software, and the extent of cell migration was determined as the average distance between the site of injection and 25-50 green cells in each slice as shown in $\boldsymbol{B}$ and $\boldsymbol{C}$. The accuracy of the injection is indicated by the green spot in $\boldsymbol{A}$, which illustrates EGFP expression after the injection of an EGFP-adenovirus into the slice. Scale bar, $500 \mu \mathrm{m}$.

groups, many of the cells costained for the astrocytic marker GFAP (Fig. 4), whereas relatively few stained for the neuronal marker NeuN (Fig. 3) (Morrow et al., 2001). Some grafted cells did not show any detectable neuronal or glial phenotype and remained poorly differentiated. We also observed that the fluorescence of grafted cells that had been in culture for 1 week or more appeared to be less pronounced in cytokine-treated slices. Indeed, we found that the average fluorescence intensity of grafted cells was reduced in cytokine-injected slices compared with controls (Fig. 6D). We investigated whether cell damage, death, or leakage of EGFP could explain this decrease in cell fluorescence. We used the TUNEL assay to measure cell death and observed that there were increased numbers of TUNEL-positive EGFP-expressing progenitor cells in cytokine-injected slices (Fig. $6 A-C$, arrows). Interestingly, however, EGFP cells with dimmer fluorescence were not all TUNEL positive (Fig. 6A-C, arrowheads), suggesting that EGFP synthesis may also be downregulated in the face of the neuroinflammatory microenvironment of the slice. When PKH26-labeled NPs were used in cytokineinjected slices (Fig. $6 A^{\prime}, C^{\prime}$ ), an increase in TUNEL response was also observed (Fig. $6 B^{\prime}, C^{\prime}$ ), although no significant decrease in PKH26 cell membrane fluorescence was noted (Fig. 6). Together, these data indicate that, while migrating, some grafted cells die (increase in TUNEL response), whereas others undergo changes in protein synthesis (decrease in EGFP fluorescence) (Fig. 6D, with no change in $\mathrm{PKH} 26$ cell membrane fluorescence).

The migratory capacity of NPs in the face of neuroinflammation was further examined using three other inflammatory stimuli in addition to TNF- $\alpha$-IFN- $\gamma$ (Fig. 7 A, B). We used HIV-1gp120, the coat protein of HIV-1 that is known to be a potent neurotoxin (Fig. $7 A^{\prime}, B^{\prime}$ ), LPS, an activator of Toll 4 receptors (Fig. $7 A^{\prime \prime}, B^{\prime \prime}$ ), and $\beta$-amyloid, which is involved in the pathogenesis of Alzheimer's disease (Fig. $\left.7 A^{\prime \prime \prime}, B^{\prime \prime \prime}, C^{\prime \prime \prime}\right)$. The $\beta$-amyloid was expressed in the slices using a $\beta$-amyloid-EGFPexpressing adenovirus. These treatments were performed $16 \mathrm{~h}$ before transplantation of progenitor cells. After treatment with each reagent over a period of $3 \mathrm{~d}$, many cells migrated away from their original transplantation site toward the site of the inflammatory stimulus. The degree to which this occurred depended on the stimulus used (Fig. 7). After $72 \mathrm{~h}$ transplantation, in the LPS-injected group, $84 \%$ of the slices exhibited migratory cells with a mean MD of $273 \pm 23 \mu \mathrm{m}$. In TNF- $\alpha-$ IFN- $\gamma$-injected slices, $75 \%$ of the slices showed migratory responses, with an MD of $181 \pm 54 \mu \mathrm{m}$, and, in HIV-1-gp120injected slices, $23 \%$ of the slices showed migration, with an MD of $123 \pm 86 \mu \mathrm{m}$.

In the experiment using the $\beta$-amyloid-EGFP adenovirus, the extent of $\beta$-amyloid expression was clearly indicated from the expression of EGFP. The major cell type expressing the $\beta$-amyloid appeared to be astrocytes. In these studies, the neural progenitors we transplanted were stained red using the membrane-soluble PKH26 dye. As can be observed in Figure $7, A^{\prime \prime \prime}, B^{\prime \prime \prime}$, and $C^{\prime \prime \prime}$, in these slices, we were able to demonstrate clear migration of red cells toward the green area of $\beta$-amyloid expression $(n=2)$.

\section{The role of chemokines in the migration of progenitor cells} toward sites of neuroinflammation

The experiments described above indicate that neural progenitors will migrate toward the injection site of different agents capable of inducing a neuroinflammatory response. In the CNS, the innate immune response involves the activation of astrocytes and microglia, resulting in the synthesis of a cascade of proinflammatory molecules, frequently initiated by TNF- $\alpha$ and followed by other cytokines and numerous chemokines (Huang et al., 2000; DeLeo et al., 2004). To demonstrate that this cascade of events occurred in these studies, we conducted experiments to demonstrate the activation of microglia in response to an inflammatory stimulus (i.e., TNF- $\alpha-$ IFN- $\gamma$ ) in the cultured slices. We cultured hippocampal brain slices from $\mathrm{CX} 3 \mathrm{CR}_{1}$-EGFP transgenic mice (Fig. $8 A, B$ ). The $\mathrm{CX}_{3} \mathrm{CR}_{1}$ chemokine receptor is the receptor for the chemokine fractalkine and is predominantly expressed in microglial cells. In the present context, it provides a useful marker for these cells whose distribution is well described by the expression of EGFP (Fig. 8A) (Davalos et al., 2005). We observed that, after the injection of TNF- $\alpha-$ IFN- $\gamma$ at various points in these slices, the area around the injection site was characterized by many EGFP-expressing microglia (Fig. $8 \mathrm{~B}$ ). We then immunostained for microglia/macrophage markers in slices that were injected with either TNF- $\alpha$-IFN- $\gamma$ (Fig. $8 A^{\prime \prime}, B^{\prime \prime}$, red) or an adenovirus expressing EGFP- $\beta$-amyloid (Fig. $8 A^{\prime \prime}, B^{\prime \prime}, C^{\prime \prime}$, red) as inflammatory stimuli. We showed that staining for CD11b (microglia) and F4/80 (macrophages) was concentrated around the 
area of the inflammatory site (Fig. 8). We then conducted an experiment in which WT-EGFP-NPs were grafted onto WT slices (all from CD1 mice) that were injected with TNF $\alpha-$ IFN- $\gamma$. First, we found that endogenous $\mathrm{CD} 11 \mathrm{~b}^{+} / \mathrm{F} 4 / 80^{+}$microglia and macrophages were present at the site of the inflammatory stimulus and displayed small round or spindle shapes (Fig. $\left.8 A^{\prime \prime}, B^{\prime \prime} D^{\prime \prime}, E^{\prime \prime}\right)$. Second, grafted EGFPexpressing cells migrated toward the site of the inflammatory stimulus (Fig. $8 B^{\prime \prime}, C^{\prime \prime}, E^{\prime \prime}$, green). Third, no CD $11 \mathrm{~b}^{+} / \mathrm{F} 4 /$ $80^{+}$macrophage cells colocalized with EGFP cells (Fig. $8 E^{\prime \prime}$, merged image). This indicates that EGFP-expressing cells observed at inflammatory sites were actually transplanted EGFP-NPs that had migrated in response to inflammation and not migrating macrophages that had taken up fluorescent debris.

Activation of microglia and astrocytes should be accompanied by upregulation of chemokine synthesis. Indeed, we observed a several fold increase in chemokine levels [e.g., MCP-1, interferon- $\gamma$ inducible protein of $10 \mathrm{kDa}$ (IP-10), RANTES (regulated on activation, normal T-cell expressed and secreted), and $\mathrm{KC}$ (the mouse growth-related oncogene $\mathrm{GRO}-\alpha$ ) and also in levels of the cytokine interleukin-6 (IL-6), in slices treated with TNF- $\alpha-$ IFN- $\gamma$ (Table 1). Similar increases were observed with HIV-1-gp120, LPS, and $\beta$-amyloid-EGFP (supplemental Table 1, available at www.jneurosci.org as supplemental material). Of importance, TNF- $\alpha-$ IFN- $\gamma$ and LPS evoked the largest stimulation of chemokine synthesis, which may explain their increased ability to produce migratory responses (Fig. 7). Of the numerous chemokines, we noted that the chemokine MCP-1/CCL2 is often highly upregulated in association with neuroinflammatory responses (Huang et al., 2000; Huang et al., 2001; Thibeault et al., 2001). MCP-1 has been shown to be responsible for the migration of leukocytes into the brain under different conditions. For example, synthesis of MCP-1 by astrocytes and microglia in the brain is primarily responsible for the influx of leukocytes that occurs after axonal damage in the brain or in association with neuroinflammatory disease such as experimental autoimmune encephalomyelitis (EAE), a rodent model of multiple sclerosis (Huang et al., 2001; Babcock et al., 2003). This stimulated us to conduct experiments examining the migration of neural progenitor cells using $\mathrm{CCR}_{2}$ $(\mathrm{B} 6 \times 129$ strain $)$ and MCP-1 [(129Sv/J $\times$ C57BL/6)F $\mathrm{F}_{1}$ strain] mutant mice. We prepared wild-type neurospheres from $\mathrm{B} 6 \times$ 129 mice and transplanted them into cultured slices from this strain. As in the case of CD1 mice (see above), in control slices (saline injection), transplanted cells remained in the vicinity of the DG injection site. In slices that were injected with TNF- $\alpha-$ IFN- $\gamma$, cells migrated toward the inflammatory stimulus. We then prepared neurospheres from $\mathrm{CCR}_{2}$ knock-out (KO) mice $(\mathrm{B} 6 \times 129$ strain $)$ and transplanted them into hippocampal slices from the same strain. The initial engraftment of these cells appeared indistinguishable from wild-type cells (Fig. 9A), most grafted NPs remaining confined to the site of transplantation. However, the behavior of the cells after treatment of slices with TNF- $\alpha$-IFN- $\gamma$ was different, the degree of migration observed being greatly reduced (Fig. $9 A, B$ ). These results suggest that activation of $\mathrm{CCR}_{2}$ receptors expressed by neural progenitors may be important in guiding their migration. We therefore conducted additional experiments in which we transplanted neural progenitors from wild-type mice, but the hippocampal slice cultures were taken from MCP-1 KO mice. In this case, we also observed a much reduced degree of migration of the transplanted progenitors toward the site of TNF- $\alpha-$ IFN- $\gamma$ injection (Fig. $9 A^{\prime}, B^{\prime}$ ). 

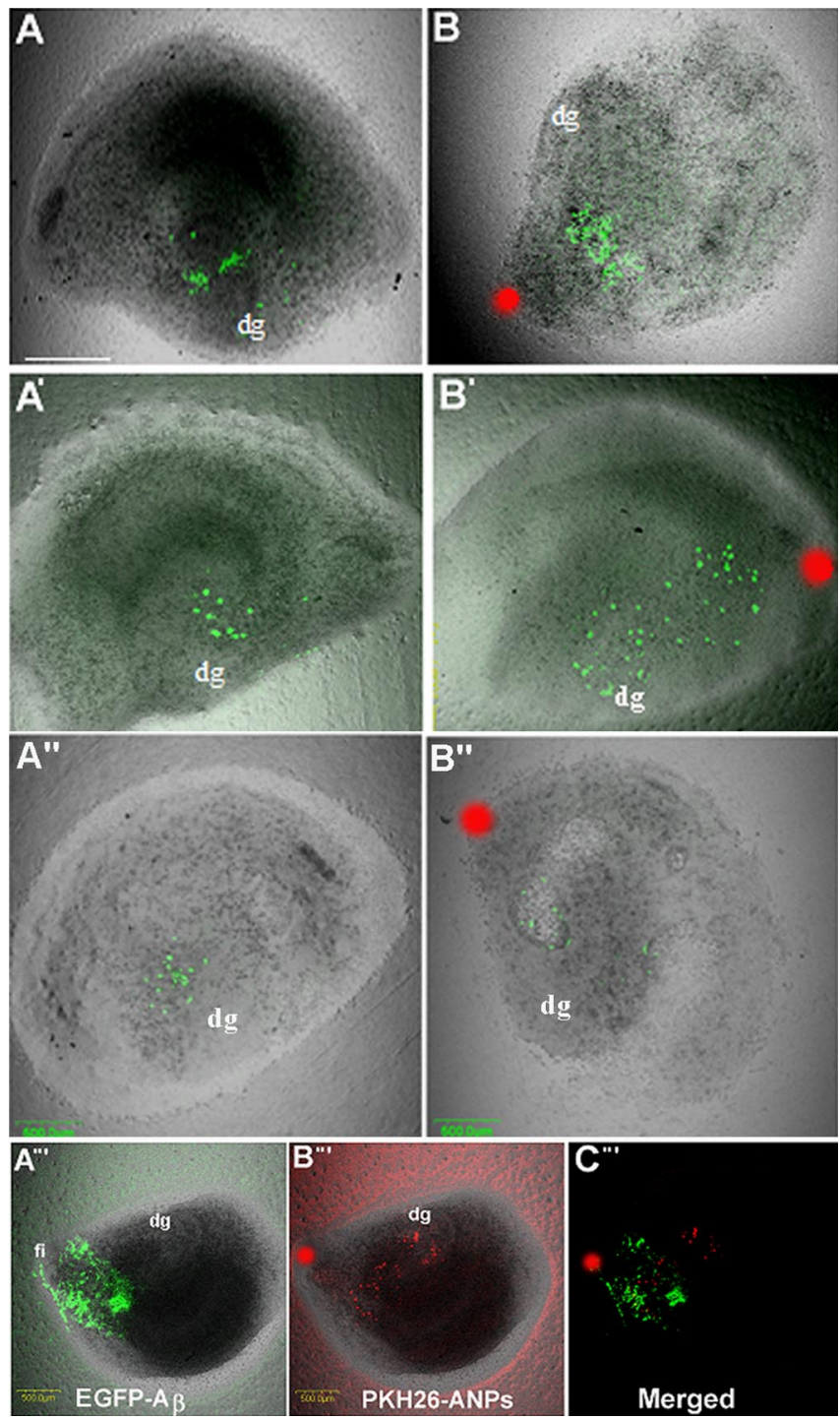

Figure 7. Migration of NPs in response to different inflammatory stimuli. EGFP-labeled NPs from wild-type CD1 mice were grafted into the area of the DG of 7-d-old hippocampal slice in control cultures $\left(A, A^{\prime}, A^{\prime \prime}\right)$. After 3 d, cells migrated toward the inflammatory site (red spot) of slices treated with TNF $\alpha-$ IFN- $\gamma(\boldsymbol{B})$, gp120-CD4 $\left(\boldsymbol{B}^{\prime}\right)$, or LPS $\left(\boldsymbol{B}^{\prime \prime}\right)$. After $72 \mathrm{~h}$ of transplantation, the extent of cell "migration" (ECM) was found in the range of $584 \pm 18 \mu \mathrm{m}$ in control slices. It increased by $54 \%$ in LPS-injected slices ( $p<0.001 ; n=3$ and 9 slices per group), $43 \%$ in TNF- $\alpha$-IFN- $\gamma$-injected slices ( $p<0.01 ; n=5$ and 9 slices per group), and $39 \%$ in HIV-1gp120-injected slices ( $p<0.001 ; n=3$ and 9 slices per group). Confocal images in $\boldsymbol{A}^{\prime \prime \prime}, \boldsymbol{B}^{\prime \prime \prime}$, and $C^{\prime \prime}$ show PKH26-labeled NPs (red) grafted into the area of the DG of 7-d-old slice cultures injected with an EGFP- $\beta$-amyloid-expressing adenovirus [fimbria (fi), green cells in $A^{\prime \prime \prime}$ ]. After $3 \mathrm{~d}$, cells migrated toward the inflammatory site (red spot in $\boldsymbol{B}^{\prime \prime \prime}, \boldsymbol{C}^{\prime \prime \prime}$ ). Scale bar, $500 \mu \mathrm{m}$.

Thus, these results indicate that MCP-1 is primarily responsible for the migration of progenitors under these neuroinflammatory conditions.

Finally, we asked whether the increased TUNEL response to neuroinflammatory stimuli was also lost with nonmigrating $\mathrm{CCR}_{2}$ mutant cells. We found that there were very few TUNEL-positive cells in both TNF- $\alpha$-IFN- $\gamma$-treated slices and control slices (Fig. 10), suggesting that both the chemotactic and the cell survival responses may be dependent on $\mathrm{CCR}_{2}$-mediated migration.

\section{Discussion}

The experiments described in this paper allow us to make two primary conclusions. First, neural progenitors will migrate to- ward sites of neuroinflammation, and, second, this may be attributable to, at least in part, the release of chemokines from activated cells participating in the neuroinflammatory response. That this should be so is consistent with several previous observations in the literature. These include observations that neural progenitors will migrate toward areas of brain injury in vivo (Picard-Riera et al., 2002; Ben-Hur et al., 2003; Kokaia and Lindvall, 2003; Parent, 2003; Imitola et al., 2004; Jin et al., 2004; Kelly et al., 2004; Glass et al., 2005; Pluchino et al., 2005), that neural progenitors express chemokine receptors (Ji et al., 2004; Krathwohl and Kaiser, 2004b; Peng et al., 2004; Tran et al., 2004a; Pluchino et al., 2005), that chemokines act as chemoattractants for these cells (Tran et al., 2004a; Widera et al., 2004; Pluchino et al., 2005), and that cells involved in neuroinflammatory responses are known to be sources of chemokine synthesis (Tran and Miller, 2003; Huang et al., 2000). It is well established that triggering the innate immune response in the brain produces neuroinflammation (DeLeo et al., 2004). This is accompanied by influx into the brain of a variety of leukocytes that contribute to additional aspects of the response (Babcock et al., 2003; Eugenin et al., 2006). Several studies have demonstrated that chemokines synthesized by activated microglia and astrocytes are the major mediators of leukocyte migration into the brain (Fife et al., 2000; Huang et al., 2001; Babcock et al., 2003;Eugenin et al., 2006). It is already apparent from studies on the development of the nervous system that chemokines can act as regulators of neural progenitor migration. Activation of CXC chemokine receptor $\mathrm{CXCR}_{4}$ expressed by embryonic neural progenitors has been shown to be important for the formation of several structures in the brain, including the cerebellum (Zou et al., 1998), dentate gyrus (Bagri et al., 2002; Lu et al., 2002), cortex (Stumm et al., 2003), and in the formation of the DRG (Belmadani et al., 2005). The use of cultured brain slices to examine the migratory potential of progenitors in response to chemokines has also been used previously. It has been demonstrated by our laboratory, and also by Bagri et al. (2002), that stromal cellderived factor-1 (SDF-1)/CXCR 4 signaling is important for the migration of embryonic progenitors from the wall of the lateral ventricle to the nascent dentate gyrus. Animals that lack $\mathrm{CXCR}_{4}$ receptors exhibit deficits in the formation of the DG attributable to incomplete migration of granule cell progenitors. Bagri et al. (2002) demonstrated the effect of SDF-1 on progenitors by forcing the expression of SDF-1 at ectopic sites in embryonic hippocampal slice cultures and observing the inappropriate migration of progenitors to these sites. In the present case, injection of an inflammatory stimulus was predicted to activate microglia and astrocytes, which would act as a source of chemokines. The secreted chemokines presumably form some type of concentration gradient within the slice. It should be noted that, in the extracellular environment, chemokines are highly susceptible to degradation by enzymes such as tissue metalloproteinases (Scotton et al., 2002; Zhang et al., 2003; Parks et al., 2004). Moreover, chemokines bind to elements of the extracellular matrix (ECM), a mechanism that has been suggested in aiding the establishment of chemokine gradients. Chemokines attached in this way are stabilized against degradation (Scotton et al., 2002). Thus, a combination of these various factors might set up chemokine gradients within the slices.

In our studies, we used several types of stimuli to initiate a neuroinflammatory response in the slice. All of these have been demonstrated to produce neuroinflammation in vivo (Mehlhorn et al., 2000; Dawson et al., 2003; Giovannini et al., 2003; Ambrosini et al., 2005). It is likely, however, that the release of TNF- $\alpha-$ IFN- $\gamma$ and other proinflammatory cytokines form a common 
link between all of these stimuli. These cytokines then trigger many events that coordinate the downstream elements of neuroinflammation, of which chemokine synthesis is clearly an important part. We found that deletion of signaling by the $\mathrm{CCR}_{2}$ chemokine receptor appeared to be particularly important in the migratory response to neuroinflammation. Several observations support this possibility. Neural progenitors express $\mathrm{CCR}_{2}$ receptors, and MCPs act as chemoattractants for these cells (Ji et al., 2004; Tran et al., 2004a; Widera et al., 2004). Furthermore, neuroinflammatory stimuli such as those used here strongly upregulate MCP-1 synthesis (Fife et al., 2000; Mehlhorn et al., 2000; Thibeault et al., 2001; Dawson et al., 2003). MCP-1 is known to be synthesized in vivo under neuroinflammatory circumstances, and it is important in the trafficking of leukocytes into the brain (Fife et al., 2000; Babcock et al., 2003; Cardona et al., 2003; Dawson et al., 2003; Eugenin et al., 2006). Thus, it seems reasonable that MCP-1 might play a similar role in the migration of progenitor cells. Our observations do suggest that several other chemokines are synthesized in response to neuroinflammatory stimuli in the slice in addition to MCP-1. For example, large quantities of IP-10, RANTES, and GRO- $\alpha$ are also made, and there are numerous other chemokines that we did not measure. Because receptors for these chemokines are similarly expressed by neural progenitors (Ji et al., 2004; Krathwohl and Kaiser, 2004b; Tran et al., 2004a), it is not completely clear why block of MCP-1/CCR 2 signaling has such a major effect. However, a similar problem applies to the major effect of this chemokine when considering its role in attracting leukocytes into the brain, because other chemokines are also synthesized under the same circumstances (Babcock et al., 2003; Eugenin et al., 2006). Clearly, therefore, the mere synthesis of a chemokine only partially explains these data. The experiments imply that other chemokines such as RANTES and IP-10 are less effective chemoattractants for neural progenitors, at least under these circumstances. The reasons for this are unclear, but there are several possibilities. For example, metabolism of SDF-1 yields a molecule that may act as an SDF-1 antagonist or other properties, and it is possible that similar things may occur in the case of other chemokines (Loetscher et al., 1998; Zhang et al., 2003). In addition, the expression of different chemokine receptors by the same cell can result in the formation of heterodimers that may enhance or reduce the effects of specific agonists. (Percherancier et al., 2005).

What evidence exists that mechanisms such as those suggested were used.
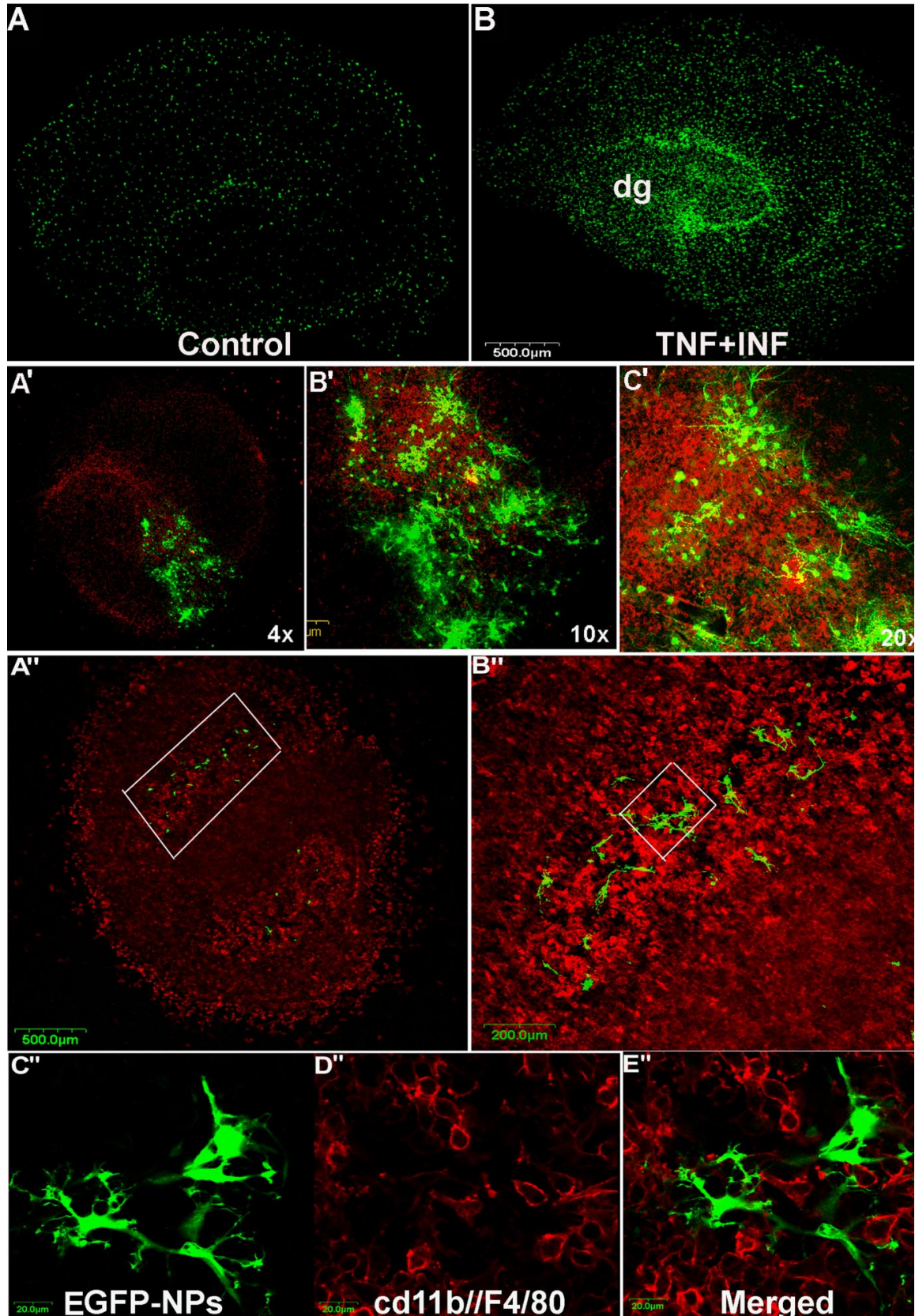

$\mathrm{D}^{\prime \prime}$

Figure 8. Activation of macrophages/microglia and migration of transplanted cells in response to inflammatory stimuli in 7-d-old hippocampal slice cultures. In $\boldsymbol{A}$ and $\boldsymbol{B}$, hippocampal slices were generated from $\mathrm{CX}_{3} \mathrm{CR}_{1}-\mathrm{EGFP}$ transgenic mice, in which EGFP-CX3CR is mostly expressed in microglia. When injected with the inflammatory stimulus (TNF- $\alpha$-IFN- $\gamma$ ) into the dentate gyrus (dg), slice shows activation of EGFP-CX3CR -expressing microglia at the site of the inflammatory stimulus $(\boldsymbol{B})$ and in control slice after saline injection $(\boldsymbol{A})$. In $\boldsymbol{A}^{\prime}, \boldsymbol{B}^{\prime}$, and $\boldsymbol{C}^{\prime}$, slices were injected with EGFP- $\beta$-amyloid-expressing adenovirus as an inflammatory stimulus. $\boldsymbol{A}^{\prime}$ is magnified in $\boldsymbol{B}^{\prime}$ (scale bar, $200 \mu \mathrm{m}$ ) and $\boldsymbol{C}^{\prime}$ (scale bar, $100 \mu \mathrm{m}$ ), showing CD11b- and F4/80-stained microglia/macrophages at the injection site of the inflammatory stimulus (red in $\left.\boldsymbol{A}^{\prime}, \boldsymbol{B}^{\prime}, \boldsymbol{C}^{\prime}\right)$. In $\boldsymbol{A}^{\prime \prime}$ and $\boldsymbol{B}^{\prime \prime}$, grafted GFP-NPs in slices injected with TNF- $\alpha$-IFN- $\gamma$ were immunostained for macrophage/microglia markers using a combined cyanine 3-conjugated monoclonal to $\mathrm{CD} 11 \mathrm{~b}^{+}$and $\mathrm{F} 4 / 80^{+}$. Box in $\boldsymbol{A}^{\prime \prime}$ is magnified in $\boldsymbol{B}^{\prime \prime}$ (scale bar, $200 \mu \mathrm{m}$ ). Box in $\boldsymbol{B}^{\prime \prime}$ is magnified in $\boldsymbol{C}^{\prime \prime}$, $\boldsymbol{D}^{\prime \prime}$, and $\boldsymbol{E}^{\prime \prime}$ (scale bar, $20 \mu \mathrm{m}$ ), which shows CD11b/F4/80-stained macrophage/microglia (red in $\boldsymbol{D}^{\prime \prime}, \boldsymbol{E}^{\prime \prime}$ ). Images in $\boldsymbol{C}^{\prime \prime}$ and $\boldsymbol{D}^{\prime \prime}$ were merged to show that there is no colocalization between migrating EGFP-NPs and activated macrophage/microglia. $n=1,9$ slices

here actually operate in vivo? Numerous papers have demonstrated the homing of neural progenitor cells to sites of brain injury. Increased neurogenesis and migration of progenitors has been noted in animal models of epilepsy, stroke, trauma, Alzheimer's disease, Parkinson's disease, and Huntington's disease (Parent, 2003). In demyelinating diseases such as EAE or in the 
Table 1. Multiplex immunoassay determinations of media cytokine and chemokine levels (picograms per milligram of protein) after $16 \mathrm{~h}$ of treatment with TNF- $\alpha$-IFN- $\gamma$

\begin{tabular}{|c|c|c|c|c|c|c|c|c|}
\hline $\mathrm{pg} / \mathrm{mg}$ protein & IL-1 $1 \alpha$ & IL-1 $1 \beta$ & IL-6 & IP-10 & KC & MCP-1 & MIP-1 $\alpha$ & RANTES \\
\hline Control slices & $13.4 \pm 4.1$ & $3.9 \pm 0.4$ & $9.9 \pm 3.6$ & $16.8 \pm 3.3$ & $37.1 \pm 9.2$ & $9.5 \pm 2.3$ & $188 \pm 101$ & $4.9 \pm 2.3$ \\
\hline TNF- $\alpha$-INF- $\gamma$-treated slices & $12.3 \pm 3.5$ & $4.3 \pm 0.7$ & $493 \pm 124^{*}$ & $289 \pm 61^{*}$ & $408 \pm 144^{* *}$ & $578 \pm 78^{* * *}$ & $232 \pm 127$ & $76 \pm 20^{* *}$ \\
\hline
\end{tabular}

Values are means \pm SEM; $n=3,2$ slices from 3 groups. MIP-1, Macrophage inflammatory protein-1. ${ }^{*} p<0.01,{ }^{* *} p<0.05$, and ${ }^{* * *} p<0.001$ compared with appropriate control values
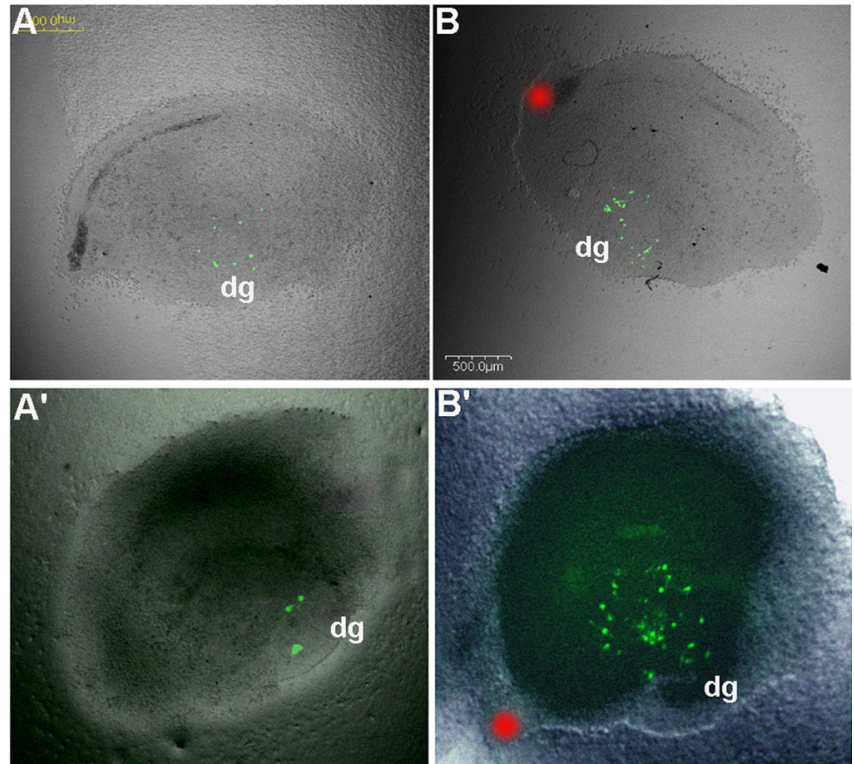

Figure 9. Migration of EGFP-NPs in response to inflammation depends on MCP-1/CCR signaling. In $\boldsymbol{A}, \boldsymbol{B}$, and $\boldsymbol{C}, \mathrm{EGFP}-\mathrm{CCR}_{2}$ KO labeled NPs (B6 $\times 129$ strain) were transplanted into the area of the $D G$ of 7- $d$-old hippocampal slice cultures from wild-type mice (B6 $\times 129$ strain). In $\boldsymbol{A}^{\prime}, \boldsymbol{B}^{\prime}$, and $\boldsymbol{C}^{\prime}$, wild-type EGFP-labeled NPs were transplanted into the area of the DG of 7-d-old slice cultures from MCP-1 KO mice. After $3 d$, cells failed to show oriented migration toward the inflammatory site (red spot) in TNF- $\alpha$-IFN- $\gamma$-treated slices $\left(\boldsymbol{B}, \boldsymbol{B}^{\prime}\right)$. The extent of cell "migration" (ECM) in cytokine-treated group was found in the same range as in control group. In $A$ and $B$, the ECM was $612 \pm 40$ versus $562 \pm 31 \mu \mathrm{m}$ in control group. In $\boldsymbol{A}^{\prime}$ and $\boldsymbol{B}^{\prime}$, the ECM was $875 \pm 45$ versus $824 \pm 87 \mu \mathrm{m}$ in control group. However, when wild-type EGFP-labeled NPs were transplanted into the area of the DG of wild-type slices (all from B6 $\times$ 129 strain), the ECM increased by $34 \%$ over control values ( $p<0.01 ; n=2$ and 9 slices per group). Scale bar, $500 \mu \mathrm{m}$.
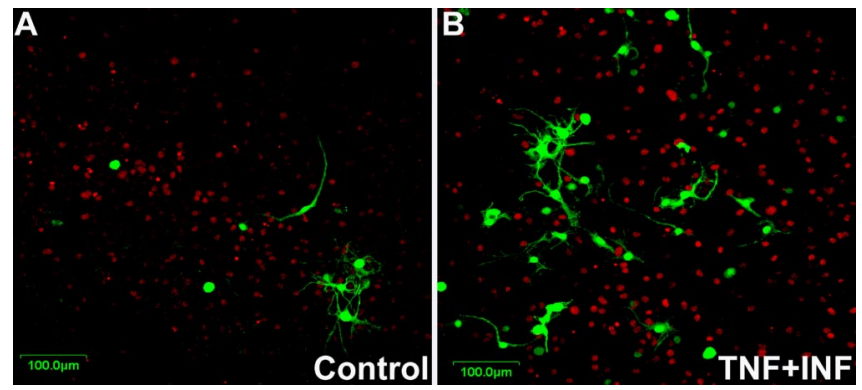

Figure 10. Role of $M C P-1 / C C R_{2}$ signaling on cell survival of migrating EGFP-NPs. EGFP$C \mathrm{CR}_{2}$ KO-labeled NPs were transplanted into the area of the DG of 7-d-old hippocampal slice cultures from wild-type mice: $\boldsymbol{A}$, control slices; $\boldsymbol{B}$, TNF- $\alpha$-IFN- $\gamma$-injected slices. In $\boldsymbol{A}$ and $\boldsymbol{B}$, double-fluorescent confocal images of neural progenitor cells: EGFP (green) and TUNEL (red). After $3 \mathrm{~d}$, cells failed to show an oriented migration toward the inflammatory site in TNF- $\alpha-$ IFN- $\gamma$-treated slices. In TNF- $\alpha$-IFN- $\gamma$-injected slices, the number of TUNEL-positive cells was in the range of $3.6 \pm 0.3 \%$ of the cells versus $3.3 \pm 0.4 \%$ in control cultures $(n=2,9-12$ slices per group). Scale bar, $100 \mu \mathrm{m}$.

shiverer mouse, progenitors migrate into the white matter in which they primarily form oligodendrocytes that remyelinate nerves, sometimes with clearly beneficial behavioral effects (Picard-Riera et al., 2002; Ben-Hur et al., 2003; Pluchino et al.,
2005). In some paradigms, these experiments were performed using transplanted progenitors such as those used here (Parent, 2003; Imitola et al., 2004; Kelly et al., 2004; Lindvall et al., 2004). These cells clearly express diverse chemokine receptors (Tran et al., 2004a; Pluchino et al., 2005). In other studies, endogenous progenitors migrated toward damaged areas of the brain. For example, a recent study demonstrated that nestin-EGFPexpressing cells migrated toward glial tumors that had been transplanted previously into the brains of adult mice (Glass et al., 2005). Few studies have examined the question of whether progenitors normally express chemokine receptors in vivo. However, $\mathrm{Lu}$ et al. (2002) did demonstrate the expression of $\mathrm{CXCR}_{4}$ by progenitors in the SGZ of the adult mouse hippocampus. In addition, we demonstrated that progenitors normally residing in the subgranular zone, SVZ, and olfactory bulb express a number of other chemokine receptors in addition to $\mathrm{CXCR}_{4}$ (Tran et al., 2004b). Interestingly, three recent studies have demonstrated that some progenitor cells on the periphery of brain lesions express $\mathrm{CXCR}_{4}$ receptors and that interference with $\mathrm{CXCR}_{4}$ mediated signaling can interfere with the migration of these cells (Imitola et al., 2004; Kao and Price, 2004; Kelly et al., 2004; Krathwohl and Kaiser, 2004a).

As our data also demonstrate, migration of progenitor cells away from the presumably neurogenic environment of the DG compromises their survival. According to data in the literature, this may be attributable to the synthesis of IL-6 at neuroinflammatory sites (Vallieres et al., 2002). Indeed, as we show here the synthesis of IL-6 is also strongly upregulated by the inflammatory stimuli in our experiments. Consequently, the ultimate effect of the neuroinflammatory milieu on the development of neural progenitors may be complex. Chemokines may act to attract progenitors to the appropriate place for repair purposes. However, on their arrival, the progenitors may also be influenced by IL-6 and other factors that may decrease their ability to survive (Monje et al., 2002, 2003). Hence, the net result of $\mathrm{CCR}_{2}$ mediated signaling may even be the ultimate overall demise of progenitor cells.

\section{References}

Aarum J, Sandberg K, Haeberlein SL, Persson MA (2003) Migration and differentiation of neural precursor cells can be directed by microglia. Proc Natl Acad Sci USA 100:15983-15988.

Aboody KS, Brown A, Rainov NG, Bower KA, Liu S, Yang W, Small JE, Herrlinger U, Ourednik V, Black PM, Breakefield XO, Snyder EY (2000) Neural stem cells display extensive tropism for pathology in adult brain: evidence from intracranial gliomas. Proc Natl Acad Sci USA 97:12846-12851.

Abrous DN, Koehl M, Le Moal M (2005) Adult neurogenesis: from precursors to network and physiology. Physiol Rev 85:523-569.

Ambrosini A, Louin G, Croci N, Plotkine M, Jafarian-Tehrani M (2005) Characterization of a rat model to study acute neuroinflammation on histopathological, biochemical and functional outcomes. J Neurosci Methods 144:183-191.

Arvidsson A, Collin T, Kirik D, Kokaia Z, Lindvall O (2002) Neuronal replacement from endogenous precursors in the adult brain after stroke. Nat Med 8:963-970.

Babcock AA, Kuziel WA, Rivest S, Owens T (2003) Chemokine expression by glial cells directs leukocytes to sites of axonal injury in the CNS. J Neurosci 23:7922-7930. 
Bagri A, Gurney T, He X, Zou YR, Littman DR, Tessier-Lavigne M, Pleasure SJ (2002) The chemokine SDF1 regulates migration of dentate granule cells. Development 129:4249-4260.

Belmadani A, Zou JY, Schipma MJ, Neafsey EJ, Collins MA (2001) Ethanol pre-exposure suppresses HIV-1 glycoprotein 120-induced neuronal degeneration by abrogating endogenous glutamate $/ \mathrm{Ca}^{2+}$-mediated neurotoxicity. Neuroscience 104:769-781.

Belmadani A, Tran PB, Ren D, Assimacopoulos S, Grove EA, Miller RJ (2005) The chemokine stromal cell-derived factor-1 regulates the migration of sensory neuron progenitors. J Neurosci 25:3995-4003.

Ben-Hur T, Einstein O, Mizrachi-Kol R, Ben-Menachem O, Reinhartz E, Karussis D, Abramsky O (2003) Transplanted multipotential neural precursor cells migrate into the inflamed white matter in response to experimental autoimmune encephalomyelitis. Glia 41:73-80.

Cardona AE, Gonzalez PA, Teale JM (2003) CC chemokines mediate leukocyte trafficking into the central nervous system during murine neurocysticercosis: role of gamma delta $\mathrm{T}$ cells in amplification of the host immune response. Infect Immun 71:2634-2642.

Davalos D, Grutzendler J, Yang G, Kim JV, Zuo Y, Jung S, Littman DR, Dustin ML, Gan WB (2005) ATP mediates rapid microglial response to local brain injury in vivo. Nat Neurosci 8:752-758.

Dawson J, Miltz W, Mir AK, Wiessner C (2003) Targeting monocyte chemoattractant protein-1 signalling in disease. Expert Opin Ther Targets $7: 35-48$.

DeLeo JA, Tanga FY, Tawfik VL (2004) Neuroimmune activation and neuroinflammation in chronic pain and opioid tolerance/hyperalgesia. The Neuroscientist 10:40-52.

Ehtesham M, Kabos P, Gutierrez MA, Chung NH, Griffith TS, Black KL, Yu JS (2002) Induction of glioblastoma apoptosis using neural stem cellmediated delivery of tumor necrosis factor-related apoptosis-inducing ligand. Cancer Res 62:7170-7174.

Eugenin EA, Osiecki K, Lopez L, Goldstein H, Calderon TM, Berman JW (2006) CCL2/ monocyte chemoattractant protein-1 mediates enhanced transmigration of human immunodeficiency virus (HIV)-infected leukocytes across the blood-brain barrier; a potential mechanism of HIV-CNS invasion in NeuroAIDS. J Neurosci 26:1098-1106.

Fife BT, Huffnagle GB, Kuziel WA, Karpus WJ (2000) CC chemokine receptor 2 is critical for induction of experimental autoimmune encephalomyelitis. J Exp Med 192:899-905.

Fricker RA, Carpenter MK, Winkler C, Greco C, Gates MA, Bjorklund A (1999) Site-specific migration and neuronal differentiation of human neural progenitor cells after transplantation in the adult rat brain. J Neurosci 19:5990-6005.

Gage FH (2002) Neurogenesis in the adult brain. J Neurosci 22:612-613.

Giovannini MG, Scali C, Prosperi C, Bellucci A, Pepeu G, Casamenti F (2003) Experimental brain inflammation and neurodegeneration as model of Alzheimer's disease: protective effects of selective COX-2 inhibitors. Int J Immunopathol Pharmacol 16:31-40.

Glass R, Synowitz M, Kronenberg G, Walzlein JH, Markovic DS, Wang LP, Gast D, Kiwit J, Kempermann G, Kettenmann H (2005) Glioblastomainduced attraction of endogenous neural precursor cells is associated with improved survival. J Neurosci 25:2637-2646.

Huang D, Han Y, Rani MR, Glabinski A, Trebst C, Sorensen T, Tani M, Wang J, Chien P, O’Bryan S, Bielecki B, Zhou ZL, Majumder S, Ransohoff RM (2000) Chemokines and chemokine receptors in inflammation of the nervous system: manifold roles and exquisite regulation. Immunol Rev 177:52-67.

Huang DR, Wang J, Kivisakk P, Rollins BJ, Ransohoff RM (2001) Absence of monocyte chemoattractant protein 1 in mice leads to decreased local macrophage recruitment and antigen-specific $\mathrm{T}$ helper cell type $1 \mathrm{im}$ mune response in experimental autoimmune encephalomyelitis. J Exp Med 193:713-726.

Ikezu T, Luo X, Weber GA, Zhao J, McCabe L, Buescher JL, Ghorpade A, Zheng J, Xiong H (2003) Amyloid precursor protein-processing products affect mononuclear phagocyte activation: pathways for sAPP- and Abeta-mediated neurotoxicity. J Neurochem 85:925-934.

Imitola J, Raddassi K, Park KI, Mueller FJ, Nieto M, Teng YD, Frenkel D, Li J, Sidman RL, Walsh CA, Snyder EY, Khoury SJ (2004) Directed migration of neural stem cells to sites of CNS injury by the stromal cell-derived factor 1alpha/CXC chemokine receptor 4 pathway. Proc Natl Acad Sci USA 101:18117-18122.

Iwai M, Sato K, Kamada H, Omori N, Nagano I, Shoji M, Abe K (2003)
Temporal profile of stem cell division, migration, and differentiation from subventricular zone to olfactory bulb after transient forebrain ischemia in gerbils. J Cereb Blood Flow Metab 23:331-341.

Ji JF, He BP, Dheen ST, Tay SS (2004) Expression of chemokine receptors CXCR4, CCR2, CCR5 and CX3CR1 in neural progenitor cells isolated from the subventricular zone of the adult rat brain. Neurosci Lett 355:236-240.

Jin K, Peel AL, Mao XO, Xie L, Cottrell BA, Henshall DC, Greenberg DA (2004) Increased hippocampal neurogenesis in Alzheimer's disease. Proc Natl Acad Sci USA 101:343-347.

Jung S, Aliberti J, Graemmel P, Sunshine MJ, Kreutzberg GW, Sher A, Littman DR (2000) Analysis of fractalkine receptor CX(3)CR1 function by targeted deletion and green fluorescent protein reporter gene insertion. Mol Cell Biol 20:4106-4114.

Kao AW, Price RW (2004) Chemokine receptors, neural progenitor cells, and the AIDS dementia complex. J Infect Dis 190:211-215.

Kelly S, Bliss TM, Shah AK, Sun GH, Ma M, Foo WC, Masel J, Yenari MA, Weissman IL, Uchida N, Palmer T, Steinberg GK (2004) Transplanted human fetal neural stem cells survive, migrate, and differentiate in ischemic rat cerebral cortex. Proc Natl Acad Sci USA 101:11839-11844.

Kokaia Z, Lindvall O (2003) Neurogenesis after ischaemic brain insults. Curr Opin Neurobiol 13:127-132.

Krathwohl MD, Kaiser JL (2004a) HIV-1 promotes quiescence in human neural progenitor cells. J Infect Dis 190:216-226.

Krathwohl MD, Kaiser JL (2004b) Chemokines promote quiescence and survival of human neural progenitor cells. Stem Cells 22:109-118.

Kuziel WA, Morgan SJ, Dawson TC, Griffin S, Smithies O, Ley K, Maeda N (1997) Severe reduction in leukocyte adhesion and monocyte extravasation in mice deficient in CC chemokine receptor 2. Proc Natl Acad Sci USA 94:12053-12058.

Lindvall O, Kokaia Z, Martinez-Serrano A (2004) Stem cell therapy for human neurodegenerative disorders-how to make it work. Nat Med [Suppl] 10:S42-S50.

Loetscher P, Gong JH, Dewald B, Baggiolini M, Clark-Lewis I (1998) $\mathrm{N}$-terminal peptides of stromal cell-derived factor-1 with CXC chemokine receptor 4 agonist and antagonist activities. J Biol Chem 273:22279-22283.

Lu B, Rutledge BJ, Gu L, Fiorillo J, Lukacs NW, Kunkel SL, North R, Gerard C, Rollins BJ (1998) Abnormalities in monocyte recruitment and cytokine expression in monocyte chemoattractant protein 1-deficient mice. J Exp Med 187:601-608.

Lu M, Grove EA, Miller RJ (2002) Abnormal development of the hippocampal dentate gyrus in mice lacking the CXCR4 chemokine receptor. Proc Natl Acad Sci USA 99:7090-7095.

Mehlhorn G, Hollborn M, Schliebs R (2000) Induction of cytokines in glial cells surrounding cortical beta-amyloid plaques in transgenic Tg2576 mice with Alzheimer pathology. Int J Dev Neurosci 18:423-431.

Monje ML, Mizumatsu S, Fike JR, Palmer TD (2002) Irradiation induces neural precursor-cell dysfunction. Nat Med 8:955-962.

Monje ML, Toda H, Palmer TD (2003) Inflammatory blockade restores adult hippocampal neurogenesis. Science 302:1760-1765.

Morrow T, Song MR, Ghosh A (2001) Sequential specification of neurons and glia by developmentally regulated extracellular factors. Development 128:3585-3594.

Parent JM (2003) Injury-induced neurogenesis in the adult mammalian brain. The Neuroscientist 9:261-272.

Parks WC, Wilson CL, Lopez-Boado YS (2004) Matrix metalloproteinases as modulators of inflammation and innate immunity. Nat Rev Immunol 4:617-629.

Peng H, Huang Y, Rose J, Erichsen D, Herek S, Fujii N, Tamamura H, Zheng J (2004) Stromal cell-derived factor 1-mediated CXCR4 signaling in rat and human cortical neural progenitor cells. J Neurosci Res 76:35-50.

Percherancier Y, Berchiche YA, Slight I, Volkmer-Engert R, Tamamura H, Fujii N, Bouvier M, Heveker N (2005) Bioluminescence resonance energy transfer reveals ligand-induced conformational changes in CXCR4 homo- and heterodimers. J Biol Chem 280:9895-9903.

Picard-Riera N, Decker L, Delarasse C, Goude K, Nait-Oumesmar B, Liblau R, Pham-Dinh D, Evercooren AB (2002) Experimental autoimmune encephalomyelitis mobilizes neural progenitors from the subventricular zone to undergo oligodendrogenesis in adult mice. Proc Natl Acad Sci USA 99:13211-13216.

Pluchino S, Zanotti L, Rossi B, Brambilla E, Ottoboni L, Salani G, Martinello 
M, Cattalini A, Bergami A, Furlan R, Comi G, Constantin G, Martino G (2005) Neurosphere-derived multipotent precursors promote neuroprotection by an immunomodulatory mechanism. Nature 436:266-271.

Scotton CJ, Wilson JL, Scott K, Stamp G, Wilbanks GD, Fricker S, Bridger G, Balkwill FR (2002) Multiple actions of the chemokine CXCL12 on epithelial tumor cells in human ovarian cancer. Cancer Res 62:5930-5938.

Stumm RK, Zhou C, Ara T, Lazarini F, Dubois-Dalcq M, Nagasawa T, Hollt V, Schulz S (2003) CXCR4 regulates interneuron migration in the developing neocortex. J Neurosci 23:5123-5130.

Thibeault I, Laflamme N, Rivest S (2001) Regulation of the gene encoding the monocyte chemoattractant protein 1 (MCP-1) in the mouse and rat brain in response to circulating LPS and proinflammatory cytokines. J Comp Neurol 434:461-477.

Tran PB, Miller RJ (2003) Chemokine receptors: signposts to brain development and disease. Nat Rev Neurosci 4:444-455.

Tran PB, Ren D, Veldhouse TJ, Miller RJ (2004a) Chemokine receptors are expressed widely by embryonic and adult neural progenitor cells. J Neurosci Res 76:20-34.

Tran PB, Ren D, Miller RJ (2004b) The role of chemokines in the guidance of migrating neural progenitor cells from postnatal brains. Soc Neurosci Abstr 30:492.16.

Vallieres L, Campbell IL, Gage FH, Sawchenko PE (2002) Reduced hippocampal neurogenesis in adult transgenic mice with chronic astrocytic production of interleukin-6. J Neurosci 22:486-492.

Widera D, Holtkamp W, Entschladen F, Niggemann B, Zanker K, Kaltschmidt B, Kaltschmidt C (2004) MCP-1 induces migration of adult neural stem cells. Eur J Cell Biol 83:381-387.

Yip S, Aboody KS, Burns M, Imitola J, Boockvar JA, Allport J, Park KI, Teng YD, Lachyankar M, McIntosh T, O'Rourke DM, Khoury S, Weissleder R, Black PM, Weiss W, Snyder EY (2003) Neural stem cell biology may be well suited for improving brain tumor therapies. Cancer J 9:189-204.

Zhang K, McQuibban GA, Silva C, Butler GS, Johnston JB, Holden J, ClarkLewis I, Overall CM, Power C (2003) HIV-induced metalloproteinase processing of the chemokine stromal cell derived factor-1 causes neurodegeneration. Nat Neurosci 6:1064-1071.

Zou YR, Kottmann AH, Kuroda M, Taniuchi I, Littman DR (1998) Function of the chemokine receptor CXCR4 in haematopoiesis and in cerebellar development. Nature 393:595-599. 